ASIMETRIS: JURNAL PENDIDIKAN MATEMATIKA DAN SAINS

$$
\text { p-ISSN } 2721 \text { - 8724, e-ISSN } 2722 \text { - } 0214
$$

Website Jurnal: http://journal.umuslim.ac.id/index.php/asm/

$\begin{array}{rll}\text { Info Artikel: } & \text { Direvisi pada 16 Mei } 2021 \\ \text { Disubmit pada 2 April 2021 } & \text { Diterima pada 17 Mei 2021 } \\ \text { Direview pada 2 Mei 2021 } & \text { Tersedia secara daring pada 17 Mei 2021 }\end{array}$

\title{
UPAYA PENINGKATAN PRESTASI BELAJAR MATEMATIKA MENGGUNAKAN PENDEKATAN PROBLEM POSING
}

\author{
Desi Rahmasari ${ }^{1}$, Oswaldus Dadi², Dessy Rizki Suryani ${ }^{3}$ \\ 1,2,3Pendidikan Matematika Universitas Musamus, Merauke, Indonesia \\ Alamat email: rahmasaridesi17@gmail.com
}

\begin{abstract}
ABSTRAK. Penelitian ini bertujuan untuk meningkatkan prestasi belajar matematika menggunakan pendekatan problem posing. Penelitian ini dilakukan sebanyak dua siklus dengan setiap siklus terdapat empat pertemuan, yaitu tiga pertemuan untuk proses pembelajaran dan satu pertemuan untuk tes akhir siklus. Subjek penelitian yang digunakan dalam penelitian adalah siswa kelas VII G SMP Negeri 2 Merauke tahun ajaran 2019/2020 yang berjumlah 35 siswa yang terdiri dari 13 siswa laki-laki dan 22 siswa perempuan. Teknik pengumpulan data yaitu tes dan observasi. Hasil penelitian yang diperoleh menunjukkan bahwa nilai ratarata tes prestasi belajar matematika siswa meningkat dari tahap pra siklus yaitu 67,21 menjadi 78,21 pada siklus 1, dan pada siklus 2 meningkat lagi mencapai 80,21 . Persentase prestasi belajar pada pra siklus mencapai $42,85 \%$ menjadi $74,29 \%$ pada siklus 1, dan meningkat pada siklus 2 mencapai $82,86 \%$ terdapat dalam kategori baik dan sangat baik. Dari hasil tersebut disimpulkan bahwa dengan pendekatan problem posing dapat meningkatkan prestasi belajar matematika siswa.
\end{abstract}

Kata Kunci: Matematika; Prestasi Belajar; Pendekatan Problem Posing.

ABSTRAK. This research is which aims to improve mathematics learning achievement using the problem posing approach. This research which was conducted in two cycles, with each cycle there were four meetings, where three meetings for the learning process and one meeting for the final test cycle. The subjects of this research were students of class VII G of SMP Negeri 2 Merauke in academic years 2019/2020, totaling 35 stedents consist of 13 male students and 27 female students. The data collecting technique in this research use test and observation. The results of this research showed that the average test score of students mathematics learning achievement increased, from the pre-cycle stage of 67.21 to 78.21 in cycle 1, and in cycle 2 it increased again to reached 80.21 . The precentage of learning achievement in pre-cycle reached $42.85 \%$ to $74.29 \%$ in cycle 1 , and increased in cycle 2 to reached $82.86 \%$ in both good and very good categories. From these result it can be cocluded that the problem posing approach can improve mathematics learning achievement in students.

Keyword: Mathematics; Learning Achievement; Problem Posing Approach

\section{I.PENDAHULUAN}

Matematika memegang kontribusi penting pada perkembangan teknologi dan ilmu pengetahuandalam setiap jenjang pendidikan. Matematika sebagai salah satu mata pelajaran yang patut diperoleh siswa mulai jenjang pendidikan dasar dan menengah serta ditegaskan kembali dalam Undang-Undang RI No. 20 Tahun 2003 (Menteri Pendidikan dan Kebudayaan, 2006) mengenai Sistem Pendidikan Nasional (Chrissanti \& Widjajanti, 2015) adapun maksud pembelajaran matematika bagi semua jenjang pendidikan yang di utarakan Menteri Pendidikan dan Kebudayaan adalah untuk menyiapkan siswa supaya mampu menghadapi perubahan keadaan yang selalu berkembang dalam kehidupan, melalui latihan bertindak atas dasar pemikiran secara rasional, kritis, jujur, teliti dan efisien.

Mata pelajaran matematika menjadi perhatian utama dalam dunia pendidikan karena dianggap sulit dan kurang digemari bagi sebagian besar siswa. Hal ini diungkapkan oleh Ompusunggu (2014) bahwa matematika pada 
kenyataannya masih merupakan pelajaran yang sulit dipelajari oleh siswa bahkan merupakan pelajaran yang menakutkan dan juga merupakan mata pelajaran yang kurang diminati atau sering dihindari oleh kebanyakan siswa. Dengan demikian, guru harus membuat siswa termotifasi dan tertarik dengan matematika dengan berbagai cara dan vasiasi dalam menggunakan pendekatan atau metode dalam proses pembelajaran.

Dalam pendidikan formal, belajar menunjukkan adanya perubahan dalam diri seseorang. Adapun cara melihat sejauh mana perubahan yang terjadi adalah dengan evaluasi. Evaluasi hasil belajar dibuat guna mengetahui seberapa besar siswa sudah memenuhi sasaran belajar yang disebut prestasi belajar. Prestasi belajar menurut Syamarro et al (2015) merupakan hasil yang dicapai oleh siswa setelah melalui tahpan belajar dan mendapatkan pengalaman serta pengetahuan matematika. Hal ini menekankan bahwa prestasi belajar siswa tidak mungkin diketahui tanpa adanya penilaian atas aktivitas belajar siswa di sekolah. Dengan adanya prestasi belajar yang baik, tentunya mengindikasikan bahwa materi yang diajarkan diserap dengan baik pada saat berlangsungnya aktivitas pembelajaran. Prestasi belajar setiap siswa berbeda hal ini dapat dipengaruhi oleh faktor eksternal yaitu keluarga, sekolah, atau lingkungan dan faktor internal yakni minat belajar siswa (Jaba et al., 2018).

Berdasarkan wawancara yang telah dilakukan bersama guru pengampuh bidang studi matematika di SMP Negeri 2 Merauke, siswa belum mampu mencapai kriteria nilai yang diinginkan. Hasil ulangan harian siswa menunjukan bahwa beberapa banyak siswa mendapatkan hasil di bawah KKM. Nilai murni rata-rata siswa kelas VII G - VII I adalah 60 dan hasil ini tidak memenuhi kriteria ketuntasan minimum sesuai ketetapan yaitu 75. Adapun tabel daftar ulangan harian siswa yang didapat, seperti berikut:
Tabel 1.1 Hasil Ulangan Harian Siswa

\begin{tabular}{ccc}
\hline Kelas & $\begin{array}{c}\text { Jumlah } \\
\text { Siswa }\end{array}$ & $\begin{array}{c}\text { Persentase } \\
\text { Prestasi }\end{array}$ \\
\hline VII G & 36 & $45 \%$ \\
VII H & 35 & $48 \%$ \\
VII I & 36 & $40 \%$ \\
\hline
\end{tabular}

Berdasarkan tabel di atas, prestasi belajar siswa tergolong rendah. Hasil tersebut perlu mendapat perhatian khusus mengingat bahwa prestasi belajar menjadi tolak ukur keberhasilan dalam proses pembelajaran. Permasalahan yang dihadapi selama proses pembelajaran berlangsung adalah siswa kurang mampu memahami dan menerapkan konsep matematika yang diberikan. Sebagian besar siswa mengalami kesulitan dalam membuat model matematika, menganalisis dan menyelesaikan masalah kontekstual yang berkaitan dengan materi yang diajarkan. Selain hal tersebut, siswa kurang memperhatikan penjelasan yang diberikan oleh guru. Kurangnya perhatian siswa dapat dikarenakan minimnya peranan siswa dalam proses pembelajaran dan proses pembelajaran yang bersifat konvensional (teacher centered). Proses pembelajaran yang mengandalkan guru sebagai pemberi seluruh informasi mengakibatkan pengalaman siswa dalam memahami materi matematika kurang berkesan, sehingga materi yang telah diajarkan mudah dilupakan.

Berdasarkan penjelasan tersebut, guru diharapkan mampu membuat proses pembelajaran berjalan semenarik mungkin sehingga siswa dapat berperan aktif dan berkesan. Guru dapat memberikan dorongan kepada siswa agar dapat membangkitkan dan mengoptimalkan potensi diri serta mengembangkan kemampuan berpikir matematika. Guru dapat menaikkan prestasi belajar matematika siswa dengan menggunakan pendekatan pembelajaran yang melibatkan siswa dalam proses pembelajaran. Pendekatan yang dapat digunakan ketika proses pembelajaran salah satunya ialah dengan menggunakan pendekatan problem posing. Adapun langkah- 
langkah pembelajaran dengan pendekatan problem posing dalam proses pembelajaran seperti pada table berikut

Tabel 1.2 Langkah-langkah pembelajaran dengan pendekatan Problem Posing.

\begin{tabular}{lll}
\hline No. & $\begin{array}{c}\text { Kegiatan } \\
\text { Guru }\end{array}$ & \multicolumn{1}{c}{ Kegiatan Siswa } \\
\hline 1. & Mengutarakan & Berusaha \\
& apersepsi dan & mengasosiasi \\
& sasaran & kan tujuan \\
pembelajaran. & yang \\
& disampaikan \\
& serta \\
& mengingat \\
& pengetahuan \\
& yang sudah \\
& didapatkan.
\end{tabular}

2. Memberikan Mengerjakan LKS bahan ajar dan membuat LKS kepada pertanyaan mengenai siswa melalui persoalan yang bekerja belum dimengerti.

kelompok serta mempersilakan siswa untuk bertanya berkaitan dengan materi pembelajaran yang tidak dipahami.

3. Mendorong Melakukan siswa agar perumusan soal $\begin{array}{ll}\text { mampu } & \text { berdasarkan } \\ \text { merumuskan } & \text { informasi dan }\end{array}$ masalah menemukan berdasarkan penyelesaiannya. kondisi yang disediakan kemudian menyelesaikan nya.

4. Mengarahkan Menyuguhkan soal

\begin{tabular}{lll}
\hline No. & \multicolumn{1}{c}{$\begin{array}{c}\text { Kegiatan } \\
\text { Guru }\end{array}$} & \multicolumn{1}{c}{ Kegiatan Siswa } \\
\hline siswa guna & serta alternatif \\
menampilkan & penyelesaian. \\
persoalan dan & \\
penyelesaian & \\
yang sudah & \\
disusun. &
\end{tabular}

5. Membahas Ikut serta dalam LKS bersama kegiatan siswa pembelajaran dan kemudian berusaha untuk dapat menyimpulkan menyimpulkan materi materi. pembelajaran.

6. Memberi Berusaha untuk kesempatan memberi komentar siswa untuk tentang materi. menyampaikan komentar atau pertanyaan mengenai materi pembelajaran.

7. Memberi PR Mengerjakan PR guna yang diberikan. memperdalam wawasan siswa.

Sumber: (Wulandari, 2011)

Silver (Mahmuzah, 2015) menyatakan bahwa pendekatan problem posing ialah suatu kegiatan dengan memiliki dua makna berlainan, yakni siswa melakukan tahap pengembangan soal matematika baru, sesuai informasi yang disampaikan dan proses merumuskan kembali masalah matematika menggunakan bahasa sendiri berdasarkan keadaan yang disediakan. Pendekatan problem posing tidak hanya mengharuskan siswa untuk mengajukan soal, tetapi diminta untuk mencari penyelesaiannya. Soal yang diajukan oleh siswa dapat dikerjakan siswa itu sendiri atau berkelompok. Dalam kasus 
ini siswa akan belajar mandiri menemukan solusi dari konsep atau persoalan yang diberikan oleh guru. Oleh sebab itu, dalam prosedur pembelajaran matematika tidak akan terpusat pada guru dan siswa akan lebih aktif dan kritis, sehingga pendekatan problem posing efektif dalam penyampaian materi pembelajaran matematika guna mencapai prestasi belajar seperti yang diharapkan. Tujuan dilakukannya penelitian ini adalah meningkatkan prestasi belajar matematika dengan menggunakan pendekatan problem posing di kelas VII G SMP Negeri 2 Merauke.

\section{METODE PENELITIAN}

Penelitian yang dilakukan adalah Penelitian Tindakan Kelas (PTK) dengan desain penilitian Kemmis \& Mc Taggart yang terdiri dari 4 prosedur, yaitu perencanaan, tindakan, observasi dan refleksi. Pendekatan pembelajaran yang digunakan adalah pendekatan pembelajaran problem posing. Penelitian dilakukan di kelas VII G SMP Negeri 2 Merauke, dengan jumlah 35 siswa yang terdiri dari 13 siswa laki-laki dan 22 siswa perempuan dengan 8 kali pertemuan. Instrumen yang digunakan dalam penelitian adalah lembar tes siklus, lembar observasi aktivitas siswa, lembar aktivitas guru dan peneliti sendiri sebagai instrumen kunci dalam pengumpulan data. Metode penghimpun data yaitu metode tes dan observasi. Sedangkan teknik analisis data adalah analisis data prestasi belajar siswa, analisis data aktivitas siswa dan aktivitas guru.

\section{HASIL PENELITIAN DAN PEMBAHASAN}

Hasil penelitian menunjukkan terdapat peningkatan prestasi belajar matematika. Peningkatan prestasi dapat dilihat dari hasil tes prestasi belajar matematika, hasil observasi aktivitas siswa dan observasi aktivitas guru dalam mengelola pembelajaran. Hasil penelitian ini akan memberikan gambaran tentang prestasi belajar matematika setelah diterapkannya pendekatan problem posing kelas VII G SMP Negeri 2 Merauke.

Tabel 3. 1 Deskripsi Nilai Tes Prestasi Belajar Matematika Siswa

\begin{tabular}{|c|c|c|c|}
\hline \multirow{2}{*}{ Deskripsi } & \multicolumn{3}{|c|}{ Tahapan } \\
\hline & Pra Siklus & Siklus I & Siklus II \\
\hline $\begin{array}{l}\mathrm{N} . \\
\text { Rata-rata } \\
\text { Prestasi }\end{array}$ & 67,21 & 78,21 & 80,21 \\
\hline $\begin{array}{l}\text { Belajar } \\
(\%)\end{array}$ & 42,85 & 74,29 & 82,86 \\
\hline $\begin{array}{l}\text { N. } \\
\text { Tertinggi }\end{array}$ & 80 & 90 & 95 \\
\hline $\begin{array}{l}\text { N. } \\
\text { Terendah }\end{array}$ & 40 & 57,5 & 65 \\
\hline
\end{tabular}

Saat siklus 1, kriteria yang ditetapkan dalam indikator keberhasilan prestasi belajar matematika siswa belum memenuhi. Hal ini bisa dilihat dari hasil tes matematika yang telah dicapai siswa, didapatkan nilai rata-rata siswa yaitu 78,21 , dengan nilai tertinggi siswa ialah 90 , serta siswa yang mendapat nilai terendah yakni 57,5. Adapun persentase prestasi belajar matematika siswa dalam kategori baik dan sangat baik mencapai $74,29 \%$, atau sebanyak 11 siswa di kategori sangat baik sebesar $31,43 \%$ serta 15 siswa dalam kategori baik sebesar $42,86 \%$, Penyebab belum tercapainya indikator keberhasilan prestasi belajar siswa dikarenakan siswa yang belum terbiasa dengan pembelajaran melalui pendekatan problem posing, sehingga siswa masih kesusahan dalam proses pembelajaran.

Kemampuan guru mengelola pembelajaran masuk pada kategori baik, dalam proses pembelajaran guru meminta siswa untuk membaca dan memahami materi pembelajaran, guru membagikan LKS lalu meminta siswa berdiskusi dengan kelompoknya guna mengerjakan soal dan membuat soal baru, setelah siswa selesai berdiskusi guru menunjuk siswa mewakili masing-masing kelompok untuk mempresentasikan perolehan pembahasannya, guru berinteraksi dengan siswa membuat tanya 
jawab dan bersama-sama membuat kesimpulan. Namun ada beberapa kekurangan yang harus diperbaiki pada saat proses pembelajaran, seperti kemampuan memberikan motivasi, memberikan apersepsi, interaksi selama proses pembelajaran, mengarahkan siswa membuat soal baru sesuai materi yang dibahas dan membimbing siswa untuk membuat kesimpulan.

Aktivitas siswa yang perlu diperhatikan dan diperbaiki pada siklus ke 2 adalah semaksimal mungkin mengatur waktu pembelajaran dengan baik, saat siswa ditunjuk guna mempresentasikan perolehan diskusinya di papan tulis siswa merasa takut, masih banyak siswa yang kurang memahami soal-soal LKS pada saat berdiskusi kelompok, siswa kurang mandiri saat menganalisis cerita yang ada di LKS dan harus membuat pertanyaannya, dan cara untuk membuat siswa lebih aktif sesuai pendekatan problem posing serta memperbaiki kekurangan-kekurangan yang mengakibatkan siswa belum memenuhi kategori yang diterapkan yaitu $75 \%$.

Pada siklus 2, beberapa kekurangan yang pada siklus 1 diperbaiki sehingga prestasi belajar matematika siswa mengalami perubahaan dan telah memenuhi kriteria yang ditetapkan pada indikator keberhasilan yaitu minimal $75 \%$. Hal ini bisa dilihat dari hasil tes prestasi belajar matematika, didapatkan nilai rata-rata siswa yaitu 80,21 , dengan nilai tertinggi siswa ialah 95 , serta siswa yang mendapat nilai terendah yakni 65 . Adapun persentase prestasi belajar matematika siswa yang terdapat dalam kategori baik dan sangat baik mencapai $82,86 \%$, atau sebanyak 11 siswa di kategori sangat baik sebesar $31,43 \%$ serta 18 siswa dalam kategori baik sebesar $51,43 \%$.

Ketuntasan belajar maupun peningkatan prestasi belajar matematika siswa tidak dialami oleh seluruh siswa. Hal tersebut dikarenakan pada proses pelaksanaan pembelajaran siklus 2 terdapat beberapa siswa yang belum mampu bekerja dengan baik dalam kelompoknya, malu untuk menanyakan konsep yang tidak dipahami, dan kurang memperhatikan penjelasan guru meskipun guru selalu memberikan penguatan dan perhatian. Walaupun masih ada kendala ataupun kekurangan yang dihadapi, pada pembelajaran siklus 2 tampak bahwa aktivitas belajar, kemampuan berpikir dan kemampuan berargumen siswa mengalami peningkatan. Sebagian besar siswa mampu menyusun pertanyaan yang sesuai dengan masalah pada LKS, memberikan alasan yang rasional dalam menyusun stategi penyelesaian, dan mampu menerapkan stategi tersebut dengan benar. Fakta tersebut sesuai dengan penelitian yang dilakukan Mahmuzah (2015) dan Jabar (2015) bahwa pembelajaran menggunakan pendekatan Probelm Posing mampu menaikkan kemampuan berpikir kritis dan kemampuan pemecahan masalah siswa dalam bermatematika.

Kemampuan guru saat mengelola pembelajaran mengalami peningkatan. Hasil observasi aktivitas guru mengelola kelas dalam pembelajaran pada siklus 1 yaitu $78,57 \%$ meningkat menjadi $80,48 \%$ pada siklus 2 . Observasi aktivitas guru siklus 1 masih banyak kekurangan yang harus dibenahi seperti kemampuan guru saat menjelaskan materi pembelajaran serta kemampuan guru dalam membimbing kelompok. Pada siklus 2 guru memperbaiki kekurangan-kekurangan tersebut sehingga hasil observasi guru mengalami peningkatan dan prestasi belajar siswa meningkat pula.

Aktivitas siswa pada siklus 2 menunjukkan bahwa selama proses pembelajaran menggunakan pendekatan problem posing mengalami peningkatan. Pada siklus 1 perolehan observasi aktivitas siswa memiliki banyak kekurangan, seperti siswa jarang masuk sekolah, siswa kurang memperhatikan penjelasan guru, dan siswa malas untuk bekerja sama dalam mengerjakan LKS sehingga aktivitas siswa rendah. Pelaksanaan pembelajaran pada siklus 2, guru dan siswa membenahi kekurangan pada siklus 1 sehingga aktivitas siswa mengalami peningkatan. Hal tersebut dilihat dari persentase aktivitas siswa yakni $60 \%$ pada siklus 1 meningkat sebesar $88,57 \%$ pada siklus 2 .

Hasil penelitian ini diperjelas dan sesuai dengan penelitian yang dilakukan oleh Wulandari 
(2011) bahwa dengan menggunakan pendekatan problem posing meningkatkan kemampuan penalaran matematis siswa. Penalaran matematis siswa dapat meningkat karena dengan diberikan lembar diskusi untuk dikerjakan secara berkelompok serta diberikan waktu untuk menyusun soal dan penyelesaiannya yang telah disusun. Penerapan pendekatan problem posing dapat meningkatkan kemampuan pemecahan masalah matematis siswa (Ardiyaningrum, 2013). Dalam penelitian tersebut hal yang dilakukan dalam pelaksanaan pembelajaran adalah mengontrol dan mengawasi siswa dalam mengerjakan LKS, memperhatikan distribusi siswa dalam pembagian kelompok dan memancing pertanyaan-pertanyaan dari siswa tentang bagian yang belum mereka pahami dalam diskusi. Dari hasil penelitian disimpulkan bahwa pendekatan problem posing dapat meingkatkan pemahaman siswa dan membuat siswa lebih aktif dalam pembelajaran sehingga prestasi belajar matematika siswa meningkat.

Berdasarkan uraian pembahasan tersebut, menunjukkan bahwa proses pembelajaran dengan menggunakan pendekatan problem posing dapat meningkatkan prestasi belajar matematika siswa. Pendekatan pembelajaran problem posing tidak dapat dikatakan sebagai pendekatan pembelajaran yang terbaik, melainkan pendekatan pembelajaran tersebut dapat dijadikan sebagai salah satu alternatif untuk meningkatkan prestasi belajar matematika. Terlaksananya proses pembelajaran berdampak positif terhadap prestasi belajar matematika siswa, sehingga sudah mencapai indikator keberhasilan yakni meningkatnya prestasi belajar siswa dan meningkatkan aktivitas siswa.

\section{SIMPULAN}

Berdasarkan hasil penelitian disimpulkan bahwa prestasi belajar matematika siswa mampu ditingkatkan dengan menggunakan pendekatan pembelajaran problem posing siswa kelas VII G SMP Negeri 2 Merauke. Hal tersebut diperlihatkan oleh indikator keberhasilan yang ditetapkan, perolehan tersebut dapat ditinjau sebagai berikut:

1. Penerapan pembelajaran menggunakan pendekatan problem posing meningkatkan prestasi belajar siswa, yang ditunjukkan dengan persentase prestasi belajar mulai siklus 1 sebanyak $74,29 \%$ meningkat menjadi $82,86 \%$ pada siklus 2 berada dalam kategori baik dan sangat baik.

2. Penggunaan pendekatan problem posing meningkatkan aktivitas belajar siswa, yang diperlihatkan melalui persentase aktivitas siswa mulai siklus 1 sebanyak $60 \%$ meningkat pada siklus 2 menjadi $88,57 \%$ terdapat pada kategori baik dan sangat baik.

Berlandaskan kesimpulan yang diperoleh dari hasil penelitian tindakan kelas yang dilakukan dalam meningkatkan prestasi belajar matematika siswa. Adapun beberapa saran yaitu:

1. Pendekatan problem possing dapat digunakan oleh guru sebagai salah satu solusi untuk meningkatkan prestasi belajar matematika siswa. Karena, dapat melatih siswa untuk membuat pertanyaan berdasarkan permasalahan yang dihadapi dan mencari solusi yang tepat untuk menyelesaikan masalah tersebut.

2. Dapat digunakan sebagai referensi dan acuan oleh peneliti selanjutnya yang akan melakuan penelitian tentang pendekatan problem possing.

\section{DAFTAR PUSTAKA}

Ardiyaningrum, M. (2013). Upaya Peningkatan Kemampuan Pemecahan Masalah Matematis Siswa Kelas Vii Smp Muhammadiyah 9 Yogyakarta Melalui Penerapan Pendekatan Pembelajaran Problem Posing. LITERASI (Jurnal IImu Pendidikan), 4(1), 53-70. https://doi.org/10.21927/literasi.2013.4(1).5 3-70

Chrissanti, M. I., \& Widjajanti, D. B. (2015). Keefektifan Pendekatan Metakognitif 
Ditinjau Dari Prestasi Belajar, Kemampuan Berpikir Kritis, Dan Minat Belajar Matematika. Jurnal Riset Pendidikan Matematika, $\quad$ 2(1), $\quad$ 51-62. https://doi.org/10.21831/jrpm.v2i1.7150

Jaba, I., Datu Palittin, I., \& Saparuddin Nur, A. (2018). Hubungan Minat Belajar dengan Prestasi Belajar Fisika Siswa Kelas XI IPA SMA Negeri 2 Merauke. Jurnal Magistra, $5(1), 62-72$.

Jabar, A. (2015). Penerapan Pendekatan Problem Posing untuk Meningkatkan Kemampuan Pemecahan Masalah pada Materi Sistem Persamaan Linear. Math Didactic: Jurnal Pendidikan Matematika, 1(2), 80-87. https://doi.org/10.33654/math.v1i2.4

Mahmuzah, R. (2015). Meningkatkan Kemampuan Berpikir Kritis Matematik Siswa Smp Melalui Pendekatan Problem Posing. Peluang, 4(1), 64-72. https://doi.org/10.35194/jp.v6i2.123

Menteri Pendidikan dan Kebudayaan. (2006). Peraturan Menteri Pendidikan Nasional RI Nomor 22.

Ompusunggu, V. D. K. (2014). Peningkatan Kemampuan Pemahaman Matematika dan Sikap Positif terhadap Matematika Siswa SMP Nasrani 2 Medan melalui Pendekatan Problem Posing. Saintech, 06(04), 93-105. Syamarro, N., Winarso, W., \& Saluky, S. (2015). Pengaruh Motivasi Dan Persepsi Siswa Pada Matematika Terhadap Prestasi Belajar Matematika Siswa Kelas VIII Di Mts Al-Hidayah Dukupuntang Kabupaten Cirebon (Pokok Bahasan Kubus Dan Balok). Eduma: Mathematics Education Learning and Teaching, 4(2), 105-111. https://doi.org/10.24235/eduma.v4i2.32

Wulandari, E. (2011). Meningkatkan Kemampuan

Penalaran Matematis Siswa Melalui Pendekatan Problem Posing Di Kelas VIII A SMP Negeri 2 Yogyakarta. In Pendidikan. 